\title{
ASSESSMENT OF KNOWLEDGE AND PRACTICE OF PREGNANT WOMEN TOWARDS IRON DEFICIENCY ANEMIA IN PORT SAID
}

\author{
Fatma Kamal Elsayed Abdo Ashry;, Hayat Imam Mohamed;, \\ Mohamed Abdel Hamed Metawie;, Nagat Salah Shalaby \\ BS, Obstetric and gynecological nursing department, Faculty of Nursing, Port Said \\ University, Prof. Maternal and Newborn health Nursing, Faculty of Nursing, Cairo \\ University, Prof. Obstetric and Gynecological, Faculty of Medicine, Port Said \\ University, Lecturer of Maternity, Obstetric, and Gynecological Nursing, Faculty of \\ Nursing, Port Said University
}

\begin{abstract}
the aim of this study was to assess the knowledge and practice of pregnant women toward iron deficiency anemia in Port Said primary health care centers. The present study was descriptive research study. It was conducted in 12 Port Said primary health care centers. The study sample consisted of 300 pregnant women. The data was collected through structured interviewing schedule to assess the knowledge and practice of pregnant women toward iron deficiency anemia in Port Said primary health care centers. Results: The study results revealed that the majority of pregnant woman $(82.33 \%)$ had mild anemia. Mean percentage of woman's knowledge was $96 \%$. The majority of them had satisfactory knowledge regarding definition, symptoms of anemia, importance of iron supplements, and side effects (88.67\%, $97.33 \%, 91.33 \%, \& 80.33 \%$ respectively). The mean percentage of woman's practice was $65.1 \%$, and the majority of them had unsatisfactory level of practice regarding use of iron supplements with fruit juice, and use of iron supplements before meals (80.67\%, \& 92.67\% respectively). Conclusions: This study concluded that most of pregnant women had mild anemia but they need more attention. The study recommended health education to all attending pregnant women in $\mathrm{MCH}$ centers should be provided to improve health practices towards to prevent iron deficiency anemia during pregnancy.
\end{abstract}

Key words: Iron deficiency anemia - Knowledge - Practice - Pregnancy 


\section{Introduction}

Anemia is one of the world's leading causes of disability, and thus one of the most serious global public health problems (WHO, 1992). It is defined as a hemoglobin concentration below $11 \mathrm{~g} / \mathrm{dl}$. And it is categorized into three levels; mild 9-11 g/dl, moderate 7-9 $\mathrm{g} / \mathrm{dl}$ and severe $<7 \mathrm{~g} / \mathrm{dl}$. It is considered an indirect cause of maternal mortality but it compounds risk for direct causes. It affects nearly half of all pregnant women in the world: $52 \%$ in developing countries compared with $23 \%$ in the developed world. (Abdel Rahman, 2008 ) .

Iron deficiency anemia (IDA) is the most common type of anemia during pregnancy. Approximately $75 \%$ of anemia occurs during pregnancy. Also $18 \%$ of women in industrialized countries are anemic, but in the developing world this figure rises to 56\%. In Egypt (as developing countries) the prevalence of anemia among pregnant women is 47\%, much higher than developed countries. (Pillitteri, 2010 \& Gabbe et al., 2007 )

woman should take prenatal vitamins containing an iron supplement of $60 \mathrm{mg}$ elemental iron as prophylactic therapy during pregnancy, if iron deficiency anemia is diagnosed increased iron dosage is recommended (elemental iron 60 to $120 \mathrm{mg} /$ day). The pregnant woman should be instructed about which foods are high in iron and which are high in ascorbic acid. If iron deficiency anemia is severe or hemoglobin less than $8.5 \mathrm{~g} / \mathrm{dl}$ and women have difficulty with oral iron therapy, intramuscular or intravenous iron dextran can be prescribed. It is important to inform the pregnant women about the significance of iron therapy. ( Lowdermilk \& Perry, 2006 \& Cunningham et al., 2005 ) .

\section{Significance of the study:}

The prevalence of anemia in pregnancy varies considerably because of differences in socioeconomic conditions, lifestyles and health-seeking behaviors across different cultures. Severely anemic pregnant women may require blood transfusion, which is not always feasible in under-resourced settings, and it may even carry some risks for blood born diseases. Primary prevention by screening and early detection is essential. Appropriate management by health education, nutritional counseling and referral is the main roles of the nurse. So the study will give the primary health centers the accurate profile about women knowledge and practice regarding iron deficiency 
anemia IDA. As well as it will have directly effect on women's health by referral and proper management.

Aim of study: This study aims to: Assess the knowledge and practices of pregnant women towards iron deficiency anemia in Port Said.

Research questions: To achieve the aim of this study، the following research questions were formulated:

- What is the knowledge of pregnant women regarding iron deficiency anemia?

- What are the practices of pregnant women towards iron deficiency anemia?

Subjects and methods: Research Design: A descriptive design was used to conduct this study. This study was conducted in Port Said primary health care centers El-Manakh, El-Arab, El-Dawahy, El-Shark, El-Zohor and Port-Fouad. ( Port-fouad (1), Port-fouad (2), El kuwait, Fatma elzahraa, El abouty, Mostafa kamel, Bank elescan, El gwhara, El manakh, El arab, Omar ebn elkhatab, Osman ebn Afan ). The sample recruited in this study consisted of 300 pregnant women

\section{Study Sample:}

All pregnant women attending the previous setting and fulfilling the following criteria:-

\section{Inclusion criteria:}

- Second and third trimester pregnant woman.

- Age (18-40) years.

\section{Exclusion criteria:}

Women who had any history of chronic medical disorder.

\section{- $\quad$ Sample Size}

A total of 300 pregnant women were recruited. The sample size was determined by using the following equation (Dobson, 1984):

$$
\mathrm{P}(1-\mathrm{P})
$$

Sample size (n) = ------- $\mathrm{Z}^{2}$

\section{$\mathrm{D}^{2}$}

$\mathrm{P}:$ the prevalence of pregnant women with iron deficiency anemia $=59 \%$

( Abu-Hasira , 2007 ). 
$\mathrm{Z}$ 2: a percentile of standard normal distribution determined by $95 \%$ confidence level $=1.96$

D: the width of the confidence interval $=\mathrm{p} / 10$

$$
, 59(1-, 59)
$$

Sample size $(\mathrm{n})=$ $3,84=267$ women

, 00348

The calculated sample size (267) pregnant women. Due to the expected nonparticipating rate (10\%), the final sample size was 300 pregnant women.

\section{Sample type}

Purposive sampling technique was followed in the present study for the 300 pregnant women.

\section{Sample Technique}

With regards to pregnant women, the total sample was divided into twelve health care centers equaling 25 for each.

\section{Sample assessment}

Table (1) Sample assessment

\begin{tabular}{|c|c|c|c|c|c|c|}
\hline Day & Saturday & Sunday & Monday & Tuesday & Wednesday & Thursday \\
\hline Clinic & & & & & & \\
\hline Port-fouad (1) & 出 & & & 出 & & \\
\hline Port-fouad (2) & & 选 & & & 毝 & \\
\hline El kuwait & & & 逢 & & & 遇 \\
\hline Fatma elzahraa & 奥 & & & 岱 & & \\
\hline El abouty & & 岱 & & & 近 & \\
\hline Mostafa kamel & & & 企 & & & 选 \\
\hline Bank elescan & 出 & & & 岱 & & \\
\hline El gwhara & & 选 & & & 出 & \\
\hline El manakh & & & 企 & & & 近 \\
\hline
\end{tabular}




\begin{tabular}{|c|c|c|c|c|c|c|}
\hline $\mathrm{El}$ arab & $\mathbb{L}$ & & & $\mathbb{E}$ & & \\
\hline Omar ebn elkhatal & & 出 & & & 齿 & \\
\hline Osman ebn afan & & & $\mathbb{s}$ & & & $\mathbb{H}$ \\
\hline
\end{tabular}

The data were collected through the working days of the week according to the table (1). There were two days for each center to reach the estimated number of the sample.

Tool of data collection: Structured interviewing schedule adopted from (AbuHasira, 2007) and modified by the researcher: To assess the prevalence of iron deficiency anemia among pregnant women in primary health care centers, also to assess the knowledge and practice of pregnant women regarding iron deficiency anemia. It was divided in to three parts:

\section{Part (1): Socio-Demographic Data:}

Socio-demographic data included age, education, employment, family monthly income, and crowding index.

\section{Part (2): Pregnant women history:}

\section{A- Menstrual history \& Obstetric data:}

Included age of menarche, rhythm, interval, and duration of menstruation. Age at first pregnancy, number of pregnancy, number of delivery, number of abortion......etc.

\section{B- Antenatal care history:}

Included number of visits of family doctor, gestational age at first visit, previous use of iron supplements, iron drugs prescribed, BMI, and hemoglobin level this data collected through interview, and measure $\mathrm{Hg}$ level in lab investigation at the primary health care center.

Part (3): Included items related to pregnant women's knowledge and practice about iron deficiency anemia:

28 multiple choices questions to assess pregnant women's knowledge and practice about iron deficiency anemia related to definition, symptoms, causes, importance of 
iron supplements, iron rich food sources, taken breakfast, taken lunch, taken dinner.....etc.

\section{Scoring system:}

For the knowledge items, a correct response was scored 1 and the incorrect 0 . For each area of knowledge, the scores of the items were summed-up and the total divided by the number of the items, giving a mean score for the part. These scores were converted into a percent score, and means and standard deviations were computed. Knowledge was considered satisfactory if the percent score was $50 \%$ or more, and unsatisfactory if less than $50 \%$.

Practice: the items reported to be done were scored "1" and the items not done were scored "0". For each area, the scores of the items were summed-up and the total divided by the number of the items, giving a mean score for the part. Theses scores were converted into a percent score, and means and standard deviations were computed. The practice was considered adequate if the percent score was $50 \%$ or more, and inadequate if less than $50 \%$.

\section{B) Operational design:-}

The operational design included preparatory phase, tools validity\& reliability, pilot and field work.

\section{Preparation phase}

The researcher, after extensive review of related literature, different studies and theoretical knowledge of various aspects of the research topic using books, articles, internet, periodicals and magazines, had prepared tools for data collection.

\section{Validity \& Reliability}

After the tools have been modified, they were ascertained by a jury consisting of five experts in the field of obstetrics and gynecology from medical and nursing faculty staff. It involved two parts:

A- The opinions of the experts for each item were recorded on a three point scale: relevant, not relevant and clear, not clear. 
B- General or overall opinion about the form.

They were requested to express their opinions and comments on the tool and provide any suggestions for any addition or omissions of items. Then necessary modifications were done. This phase was carried out in a period of one month.

\section{Pilot Study:}

The modified items were tested through a pilot study, which was carried out on $10 \%$ of pregnant women's and centers from the selected settings. These were not included in the main sample. The main purposes of the pilot study was to test the validity and relevance of tools, to test the clarity, feasibility of the tools, whether it was understandable, to determine the time needed to fill the tool and to find out any problem that might interfere with the process of data collection. The tool was collect and fills by researcher in interview with participants.

\section{Field work}

Data was collected from the selected settings by the researcher using the tools designed in the previous phase, the process of data collection took five months from the beginning January (2012) to the end of May (2012). Six days per week were specified for data collection. The purpose of the study was explained to them prior to answering. In addition, the researcher interviewed and filled the questionnaire from each pregnant woman individually, the researcher measured BMI and hemoglobin level at time of interview. The approximate time spent with each pregnant woman during the interview was 15 to 30 minutes, interviewed woman ranged between 1 to 6 pregnant women per day.

\section{C) Administrative design:}

An official letter from the Dean of the Faculty of Nursing was sent to the director of the selected setting of the study. The director of each clinic was contacted and informed in order to obtain permission to conduct the study at the center.

\section{Ethical Consideration:}


1- The researcher explained the aim of the study to each woman to ensure their awareness about the study.

2- Oral consent was obtained after a brief explanation of the study to women to assure that the information obtained will be confidential and used only for the purpose of the study and will maintain their privacy.

\section{D) Statistical design:-}

\section{Statistical Analysis:}

Data entry and analysis were done using SPSS 11.0 statistical software packages. Quality control was done at the stages of coding and data entry.

Data were presented using descriptive statistics in the form of frequencies and percentages for qualitative variables, means and standard deviations for quantitative variables.

Qualitative variables were compared using chi-square test. Whenever the expected values in one or more cells in a $2 \times 2$ tables was less than 5 , Fisher exact test was used instead. In larger than $2 \times 2$ cross-tables, no test could be applied whenever the expected value in $10 \%$ or more of the cells was less than 5. Statistical significance was considered at $\mathrm{P}$-value $<0.05$.

\section{Results:}

Table 1 shows the demographic characteristics of the study sample. The mean age was 27.13 \pm .971 of age group 25-29 years old. A large number were secondary educated, housewives, had sufficient monthly income, and crowding index.

Figure 1 illustrate that the majority of pregnant women $(87.33 \%)$ had information from the public.

Table 2 shows that there were statistically significant relations between, the monthly income of pregnant women and crowding index and their hemoglobin level. The higher level of hemoglobin was significantly found among pregnant women who had sufficient monthly income, also hemoglobin was lower among pregnant women had crowding index exit, also there were statistically significant relations between, amount 
of menstruation and numbers of pregnancies and hemoglobin level. The higher level of hemoglobin was significantly found among pregnant women who had heavy amount of menstruation, also hemoglobin was higher among pregnant women were gravida 2 and more.

Table 3 shows that there were statistically significant relations between, number of delivery, current duration of pregnancy and body mass index (BMI) and their knowledge. The higher level of satisfactory knowledge was significantly found among pregnant women who were primipara, also satisfactory knowledge was higher among pregnant women were in second trimester. While unsatisfactory knowledge was higher among pregnant women were overweight.

Table 4 shows that, there were statistically significant relations between age at marriage, age at first pregnancy and their practice. Satisfactory practices were statistically higher among pregnant women in age group 21 and less than 25 years old.

Table 5 shows that there was a highly statistically significant relation between, use of iron supplement before meals and hemoglobin level. Moreover, there was a statistically significant relation between taking breakfast, taking lunch and taking dinner and hemoglobin level. Finally, there was a highly statistically significant relation between total practice and women hemoglobin level. The higher level of hemoglobin was significantly found among unsatisfactory level of practice towards use of iron supplement before meals, while the higher level of hemoglobin were significantly found among satisfactory level of practices towards take breakfast, take lunch, and take dinner.

\section{Discussion:}

Researcher will discuss the answers of the stated research questions: What is the prevalence of iron deficiency anemia among pregnant women in primary health care centers?, What is the knowledge of pregnant women regarding iron deficiency anemia?, and What are the practices of pregnant women towards iron deficiency anemia?

Almost one-fifth of the sample reported a hemoglobin level less than $9 \mathrm{~g} / \mathrm{dl}$, the majority of them had mild anemia. This result might be interpreted by the fact that $70 \%$ of pregnant women were multigravida 2 or more, $26.67 \%$ of them were multipara or more, also $15.33 \%$ of them their order of current pregnancies from 4- 
10. Also $48.33 \%$ of them were had heavy amount of menstruation during past menstrual history.

Idowu et al., (2004) who reported that more than half of pregnant women had moderate anemia, two-fifths of pregnant women had mild anemia. This finding agrees with Ubah, (2011) who found that the highest percentage of studied sample had mild anemia, and about one-third of them had moderate anemia. Also the study revealed that more than half of pregnant women were in the age group (25-34) years old, the lowest percentage of them were illiterate, more than two-fifths of pregnant women had secondary education and enough monthly income. This figure reflects the characteristics of Egyptian women as the age of marriage, increased educational levels are expected to improve knowledge and hence it is expected to reflect more awareness regarding health problems. In addition the pregnant women were not being able to pay the required attention to their body needs of nutrients because of their low monthly income. Abd Elhameed et al., (2012) found the same result. While Haniff, (2007) reported that the highest percentage of study sample had secondary school. On the contrary, Rosmawati et al., (2012) demonstrated that the highest level of studied women had a high level of education.

As regards the relation between hemoglobin level and socio-demographic characteristics among pregnant women, the present study revealed that there was a positive statistically significant relation between family monthly income of pregnant women and crowding index and their hemoglobin level. This may be due to that iron deficiency anemia in pregnancy was reported to be often associated with low socioeconomic status, multiple pregnancies, extremes of maternal age, and smoking, all of which independently account for the poor pregnancy outcomes. This finding contradicted with Abu-Hasira, (2007) and Abdelhafez \& El-Soadaa, (2012) who mentioned that there were no significant relations between family monthly income of pregnant women and crowding index and their hemoglobin level.

The present study revealed that the majority of pregnant women had satisfactory level of knowledge related to definition and iron rich food sources (source of iron supplements), about two-thirds of them had satisfactory level of knowledge about causes of anemia. This might be due to that iron deficiency anemia is an important and public problem, so most of pregnant women had enough information about this 
disease and its treatment. This might be interpreted by the fact that slightly less than half $(45 \%)$ of pregnant women had secondary education, $29 \%$ of them had highly education. These findings are in the same line with Kalimbira et al., (2009) who found same results.

Finally, there was a statistically significant relation between total practice and iron deficiency anemia, while there was no statistically significance between knowledge and iron deficiency anemia. This finding may be due to those three-fourths of pregnant women made antenatal visits less than 4 times. This may be due to that most of them visited centers only for tetanus vaccine. Another cause was that the protocol of visiting in centers was at the fourth month of pregnancy, this may lead to not enough time to know how to apply the knowledge known from public information.

\section{Conclusion}

In view of the findings, the study concluded that most of pregnant women had mild anemia but needed more attention. Also, the great majority of pregnant women had satisfactory knowledge and practice towards iron deficiency anemia. Pregnant women had satisfactory level of knowledge, inspite of that many points of practice had unsatisfactory level.

\section{Recommendations}

This study recommends that there is a need for health education to all attending pregnant women in $\mathrm{MCH}$ centers are provided about balanced diet and source of iron rich food, encourage women for early registration during pregnancy and also to attend postnatal visits during lactation for close supervision and effective follow-up. Further Researches: In-service training programs to all Nurses s about prenatal nursing care. As well, nursing care standards should be applied in $\mathrm{MCH}$ centers to improve the care provided for pregnant women especially counseling about balanced diet, source of iron rich food and satisfied practice about iron deficiency anemia. 


\section{References}

- Abd ElHameed H.S., Mohammed A.I., Abd El Hameed L.T. (2012): Effect of Nutritional Educational Guidelines among Pregnant Women with Iron Deficiency Anemia at Rural Areas in Kalyobia Governorate, Community Heath Nursing Department, Maternal and Newborn Health Nursing Department Faculty of Nursing, Benha University, Life Science Journal, 9 (2): 1212-1217.

- Abdel Rahman A.E.H.M.(2008): Types of anaemia among Egyptian pregnant women. Published thesis, Ain Shams Un., Fac. Med., M.Sc.

- Abdelhafez A.M., El-Soadaa S.S.(2012): Prevalence and Risk Factors of Anemia among a Sample of Pregnant Females Attending Primary Health Care Centers in Makkah, Saudi Arabia, Faculty of Medicine, Public Health Department, Ain Shams University, Cairo, Egypt, Pakistan Journal of Nutrition 11 (12): 1113-1120.

- Abu-Hasira A. W.(2007): Iron deficiency anemia among pregnant women in Nablus district; prevalence, knowledge, attitude and practices. Published thesis, An-Najah national Un. , Fac. Graduate studies, M.Sc.

- Cunningham F.G., Hauth J.C., Leveno K.J., Gilstrap L., Bloom S.L., Wenstrom K.D.(2005):Williams obstetrics, $22^{\text {nd }}$ ed., United State of America, McGraw-Hill medical publishing division, P. 129-130.

- Haniff J.(2007): Anemia in pregnancy in Malaysia: a cross-sectional, Original Article, 16 (3):527-536.

- Idowu O.A., IMafiana C.F., Sotiloye(2004): A Survey of Anemia Among Pregnant Women in Abeokuta, Nigeria, Proceedings of the International conference on Sciences \& National Development, $25^{\text {th }}-28^{\text {th }}$ October 2004.

- Kalimbira A., Kalimbira A.A., Mtimuni B.M., Chilima D.M. (2009): Maternal Knowledge And Practices Related To Anaemia And Iron Supplementation In Rural Malawi: A Cross Sectional Study, Department of Home Economics/Human Nutrition, Bunda College of Agriculture, University of Malawi, 9 (1): 550-564.

- Lowdermilk D.L., Perry S.E., Cashion K.(2010): Maternity Nursing, $8^{\text {th }}$ ed., Canada, Mosby Elsevier, p. 163- 610.

- Pillitteri A.(2010): Maternal \& child health nursing: care of the childbearing \& childbearing family, $6^{\text {th }}$ ed., China, Wolters Kluwer Lippincott Williams \& Wilkins, p. 522.

- Recce E.A., Hobbins J.C., Gant N.F.(2007): Clinical obstetrics the fetus \& mother, $3^{\text {rd }}$ ed., Blackwell publishing, p. 851. 
- Rosmawati N.N., Nazri S.M., Ismail I.M.(2012): The Rate and Risk Factors for Anemia among Pregnant Mothers in Jerteh Terengganu, Malaysia, Department of Community Medicine, School of Medical Science, Health Campus, University Sains Malaysia, Community Medicine \& Health Education, 2 (5): 2-4.

- Ubah O.P. (2011): Anemia in Pregnancy is it A Persisting Public Health Problem in Porto Novo Care Verde?, Published thesis, Medical Technologist, Department of Medical laboratory Clinic, Hospital of Porto Novo- Cape Verde.

Table (1): Socio-demographic characteristics of pregnant women $(n=300)$

\begin{tabular}{||c|l|l||}
\hline \multicolumn{1}{|c|}{ Personal characteristics } & No. & $\%$ \\
\hline Age (years): & 97 & 32.33 \\
$25-$ & 115 & 38.33 \\
$30-$ & 55 & 18.33 \\
$35-$ & 33 & 11 \\
\hline Range & $18-40$ \\
Mean \pm SD & $27.13 \pm .971$ \\
\hline Education & 31 \\
\hline Can not read \& write & 47 & 10.33 \\
Primary education & 135 & 15.67 \\
Secondary education & 87 & 45 \\
High education & 29 \\
\hline Employment & 243 \\
\hline Housewife & 57 & 81 \\
Employed & 63 \\
\hline Family monthly income & 123 \\
\hline Less than 500 (not sufficient) & 114 \\
500- (sufficient) & $930 \pm .890$ \\
More than 1000 (more than sufficient) & 31 \\
\hline Mean \pm SD & 66 \\
\hline Crowding index & 234 \\
\hline Not exit & 78 \\
Exit & \multicolumn{2}{|l||}{} \\
\hline
\end{tabular}


Figure (1): Source of information about anemia

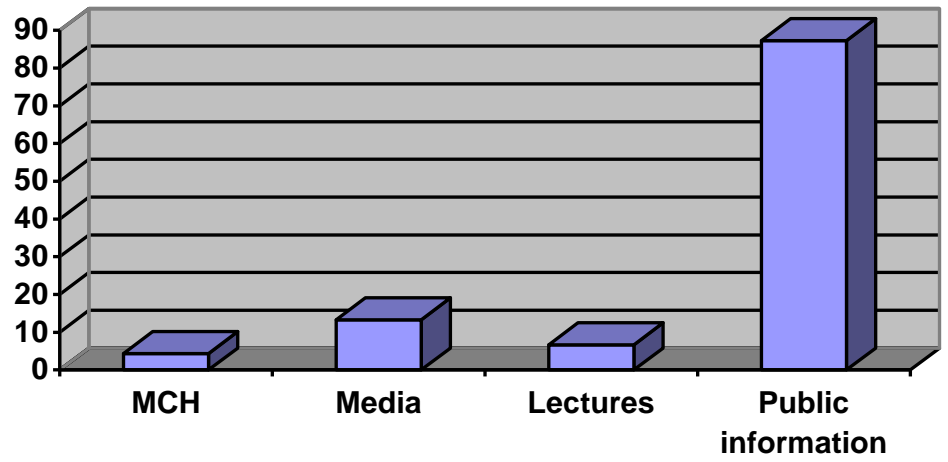

Table (2): Relationship between women's hemoglobin level and Sociodemographic and obstetric data

\begin{tabular}{|c|c|c|c|c|c|c|}
\hline \multirow[t]{2}{*}{ Items } & \multicolumn{2}{|c|}{$\begin{array}{c}\text { HB Level } \geq 9 \\
\text { N=247 }\end{array}$} & \multicolumn{2}{|c|}{$\begin{array}{c}\text { HB Level } \leq 9 \\
N=53\end{array}$} & \multirow[t]{2}{*}{$\mathbf{X}^{2}$} & \multirow[t]{2}{*}{ P-value } \\
\hline & No. & $\%$ & No. & $\%$ & & \\
\hline \multicolumn{7}{|l|}{ Family monthly income } \\
\hline $\begin{array}{l}\text { Less than } 500 \text { (not } \\
\text { sufficient) } \\
500 \text { - (sufficient) } \\
\text { More than } 1000 \text { (more } \\
\text { than sufficient) }\end{array}$ & $\begin{array}{l}45 \\
103 \\
99\end{array}$ & $\begin{array}{l}18.218 \\
41.7 \\
40.08\end{array}$ & $\begin{array}{l}18 \\
20 \\
15\end{array}$ & $\begin{array}{l}33.96 \\
37.735 \\
28.3\end{array}$ & 12.797 & $.046 *$ \\
\hline \multicolumn{7}{|l|}{ Crowding index } \\
\hline $\begin{array}{l}\text { Not exit } \\
\text { Exit }\end{array}$ & $\begin{array}{l}85 \\
189 \\
\end{array}$ & $\begin{array}{l}34.4 \\
76.5 \\
\end{array}$ & $\begin{array}{l}8 \\
45 \\
\end{array}$ & $\begin{array}{l}15.09 \\
84.9 \\
\end{array}$ & 6.071 & $.048 *$ \\
\hline \multicolumn{7}{|l|}{ Amount } \\
\hline $\begin{array}{l}\text { Little } \\
\text { Moderate } \\
\text { Heavy } \\
\end{array}$ & $\begin{array}{l}3 \\
116 \\
128 \\
\end{array}$ & $\begin{array}{l}1.2 \\
46.96 \\
51.8 \\
\end{array}$ & $\begin{array}{l}2 \\
34 \\
16 \\
\end{array}$ & $\begin{array}{l}3.77 \\
64.15 \\
30.188 \\
\end{array}$ & 9.712 & $.046 *$ \\
\hline \multicolumn{7}{|l|}{ Number of pregnancies } \\
\hline $\begin{array}{l}\text { Primigravida } \\
\text { 2- Gravida }\end{array}$ & $\begin{array}{l}80 \\
167 \\
\end{array}$ & $\begin{array}{l}32.388 \\
67.6 \\
\end{array}$ & $\begin{array}{l}10 \\
43 \\
\end{array}$ & $\begin{array}{l}18.867 \\
81.13 \\
\end{array}$ & 6.993 & $.030 *$ \\
\hline
\end{tabular}

(*) significance level at $\mathbf{p}<0.05$ 
Table (3): Relationship between Obstetric data and level of knowledge among pregnant women

\begin{tabular}{|c|c|c|c|c|c|c|}
\hline \multirow{3}{*}{ Obstetric data } & \multicolumn{4}{|c|}{ Knowledge } & \multirow{3}{*}{$\mathbf{X}^{2}$} & \multirow{3}{*}{ P-value } \\
\hline & \multicolumn{2}{|c|}{$\begin{array}{c}\text { Satisfactory } \\
\mathbf{N}=\mathbf{2 8 8}\end{array}$} & \multicolumn{2}{|c|}{$\begin{array}{c}\text { Unsatisfactory } \\
\quad \mathrm{N}=12\end{array}$} & & \\
\hline & No. & $\%$ & No. & $\%$ & & \\
\hline \multicolumn{7}{|l|}{ Number of delivery } \\
\hline Nullipara & 96 & 33.33 & 7 & 58.33 & & \\
\hline Primipara & 117 & 40.625 & 0 & & 8.027 & $.018 *$ \\
\hline From 2- & 75 & 26.04 & 5 & 41.67 & & \\
\hline \multicolumn{7}{|c|}{ Current duration of pregnancy } \\
\hline Second trimester & 177 & 71.659 & 3 & 25 & 6.380 & $.012 *$ \\
\hline Third trimester & 111 & 38.54 & 9 & 75 & & \\
\hline \multicolumn{7}{|l|}{ BMI } \\
\hline Below 18.5 (underweight) & 3 & 1.04 & 1 & 8.33 & & \\
\hline From 18.5- 24.9 (normal) & 54 & 18.75 & 0 & & 8.547 & $.036 *$ \\
\hline From 25- 29.9 (overweight) & 127 & 44.097 & 8 & 66.67 & & \\
\hline From 30 and above (obese) & 104 & 36.11 & 3 & 25 & & \\
\hline
\end{tabular}

(*) significance level at $\mathbf{p}<0.05$

Table (4): Relationship between Obstetric data and practice among pregnant women

\begin{tabular}{|c|c|c|c|c|c|c|}
\hline \multirow{3}{*}{ Obstetric data } & \multicolumn{4}{|c|}{ Practice } & \multirow{3}{*}{$\mathbf{X}^{2}$} & \multirow{3}{*}{ P-value } \\
\hline & \multicolumn{2}{|c|}{$\begin{array}{c}\text { Satisfactory } \\
\mathbf{N}=\mathbf{2 2 2}\end{array}$} & \multicolumn{2}{|c|}{$\begin{array}{c}\text { Unsatisfactory } \\
\quad \mathrm{N}=87\end{array}$} & & \\
\hline & No. & $\%$ & No. & $\%$ & & \\
\hline \multicolumn{7}{|l|}{ Age at marriage (years) } \\
\hline $18-$ & 73 & 32.88 & 38 & 48.7 & & \\
\hline 21- & 86 & 38.7 & 24 & 30.76 & 8.312 & $.040 *$ \\
\hline $25-$ & 48 & 21.6 & 15 & 19.23 & & \\
\hline $30-$ & 15 & 6.7 & 1 & 1.28 & & \\
\hline \multicolumn{7}{|l|}{ Age at first pregnancy } \\
\hline $18-$ & 64 & 28.8 & 35 & 44.87 & & \\
\hline 21- & 88 & 39.6 & 27 & 34.6 & 10.094 & $.018 *$ \\
\hline $25-$ & 50 & 22.5 & 15 & 19.23 & & \\
\hline $30-$ & 20 & 9 & 1 & 1.28 & & \\
\hline
\end{tabular}

(*) significance level at $\mathbf{p}<0.05$ 
Table (5): Relationship between women's practice and hemoglobin level

\begin{tabular}{|c|c|c|c|c|c|c|}
\hline \multirow[t]{2}{*}{ practice } & \multicolumn{2}{|c|}{$\begin{array}{c}\text { HB Level } \geq 9 \\
\mathrm{~N}=\mathbf{2 4 7}\end{array}$} & \multicolumn{2}{|c|}{$\begin{array}{c}\text { HB Level } \leq 9 \\
\mathrm{~N}=53\end{array}$} & \multirow[t]{2}{*}{$\mathbf{X}^{2}$} & \multirow[t]{2}{*}{ P-value } \\
\hline & No. & $\%$ & No. & $\%$ & & \\
\hline $\begin{array}{l}\text { Use of iron supplement before } \\
\text { meals } \\
\text { Satisfactory } \\
\text { Unsatisfactory } \\
\end{array}$ & $\begin{array}{l}17 \\
230\end{array}$ & $\begin{array}{l}6.88 \\
93.3\end{array}$ & $\begin{array}{l}5 \\
48\end{array}$ & $\begin{array}{l}9.43 \\
90.56\end{array}$ & 12.720 & $.002 * *$ \\
\hline $\begin{array}{l}\text { Take breakfast } \\
\text { Satisfactory } \\
\text { Unsatisfactory } \\
\end{array}$ & $\begin{array}{l}191 \\
56 \\
\end{array}$ & $\begin{array}{l}77.3 \\
22.67 \\
\end{array}$ & $\begin{array}{l}46 \\
7 \\
\end{array}$ & $\begin{array}{l}86.79 \\
13.2 \\
\end{array}$ & 6.984 & $.030 *$ \\
\hline $\begin{array}{l}\text { Take lunch } \\
\text { Satisfactory } \\
\text { Unsatisfactory } \\
\end{array}$ & $\begin{array}{l}242 \\
5 \\
\end{array}$ & $\begin{array}{l}97.975 \\
2.024\end{array}$ & $\begin{array}{l}47 \\
6 \\
\end{array}$ & $\begin{array}{l}88.679 \\
2.429 \\
\end{array}$ & 11.047 & $.004 * *$ \\
\hline $\begin{array}{l}\text { Take dinner } \\
\text { Satisfactory } \\
\text { Unsatisfactory } \\
\end{array}$ & $\begin{array}{l}181 \\
66 \\
\end{array}$ & $\begin{array}{l}73.279 \\
26.72 \\
\end{array}$ & $\begin{array}{l}20 \\
33 \\
\end{array}$ & $\begin{array}{l}37.735 \\
62.26 \\
\end{array}$ & 25.590 & $\begin{array}{l}.0001 * * \\
*\end{array}$ \\
\hline
\end{tabular}

(*) significance level at $\mathbf{p}<0.05$ 


\title{
تقييم معلومات و ممارسات السيدات الحوامل تجاه انيميا نقص الحديد في مراكز الرعاية

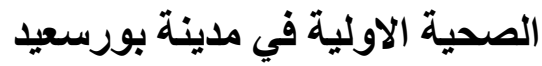

\author{
فاطمة كمال عشري ، أ .د ـ حياة الإمام محمد، أ .د ـ محمد عبد حامد مطاوع، دـ ـ نجاة صلاح شلبى
}



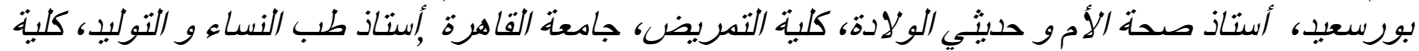

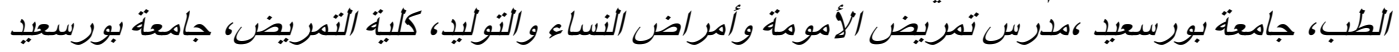
الملخص العربي النياء

انيميا نقص الحديد لدى الحوامل بشكل مصدر قلق حقيقي في جميع أنحاء العالم و بالاخص في البلدان النامية.

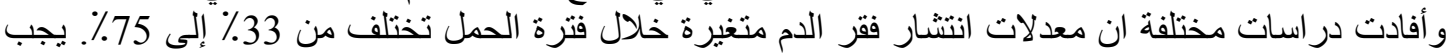

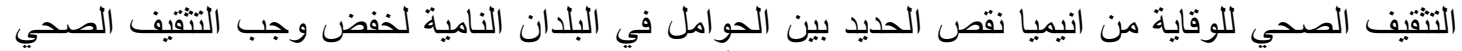

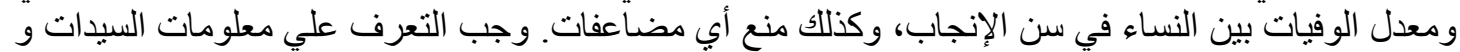

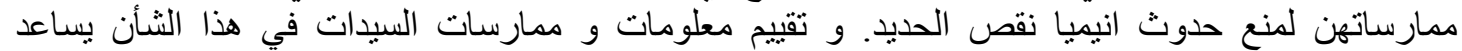
المنظمات الصحية علي تقديم البرامج المناسبة للتغلب علي أي نقص المباتي في المعلومات أو تقصير في الممارسات

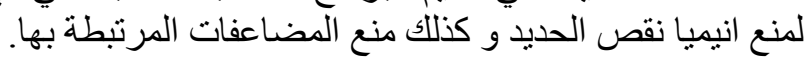

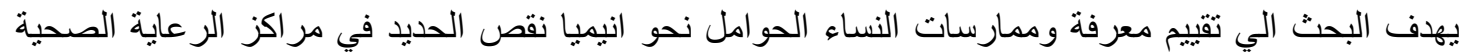

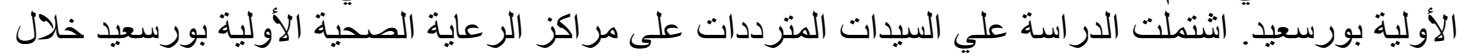

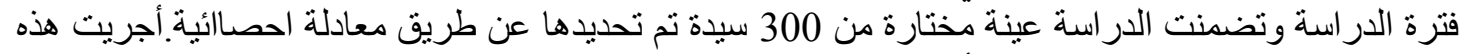

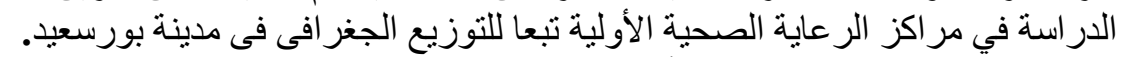

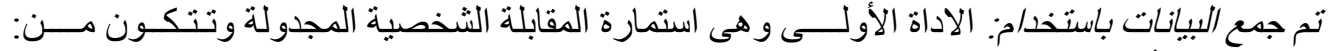

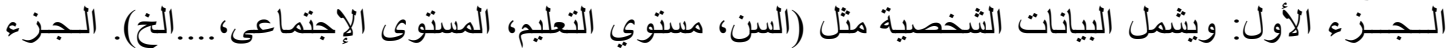

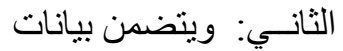

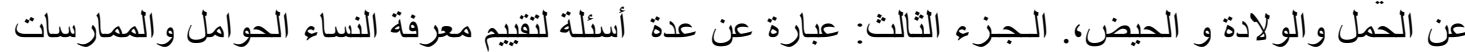
حول انيميا نقص الحديد مثل التعريف، الأعر اض، والأسباب،.....الخ. تم الانتهاء من جمع البيانات خلال الفترة

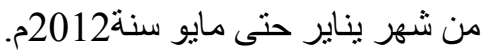

أسفرت نتائج الدراسة عما يلي: فيما يتعلق بمستوى الهيمو غلوبين بين النساء الحوامل، وكان 17.33 1.3ن فنهم فقر

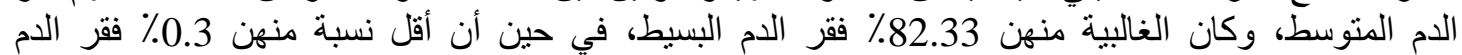

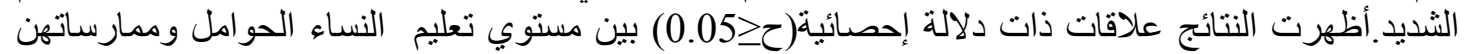

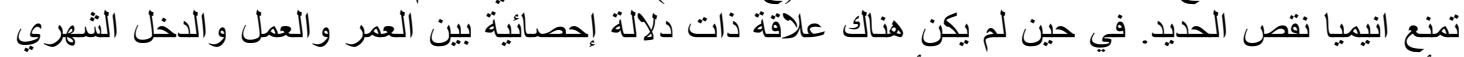

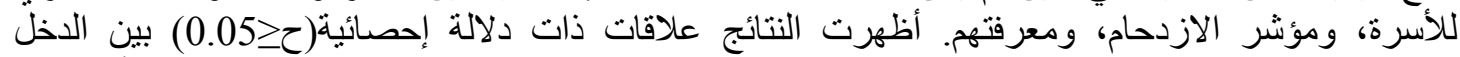

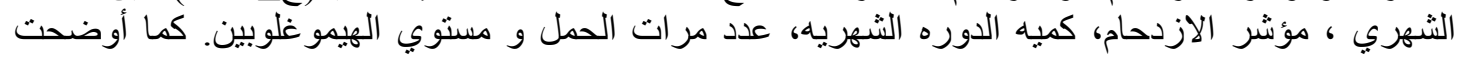

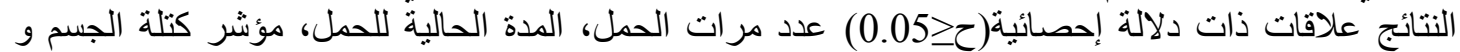

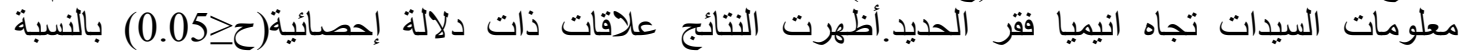

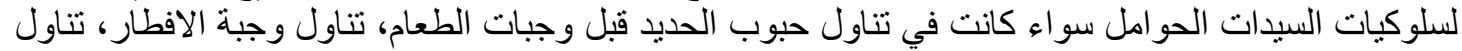
وجبة الغداء، تناول وجبة العشاء و ممارسات السيدات تجاء الناه انيميا فقر الحديد.

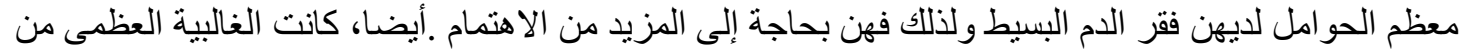

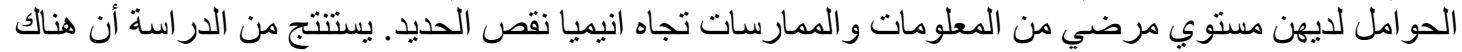

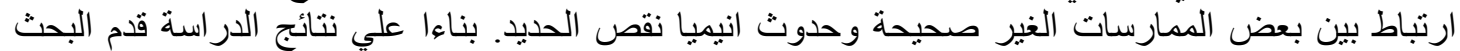

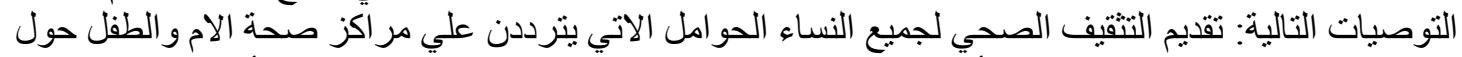

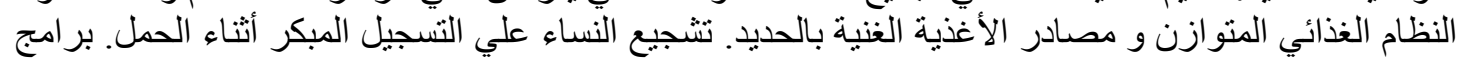

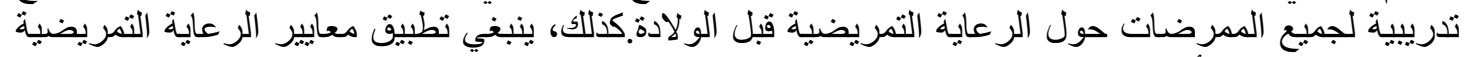

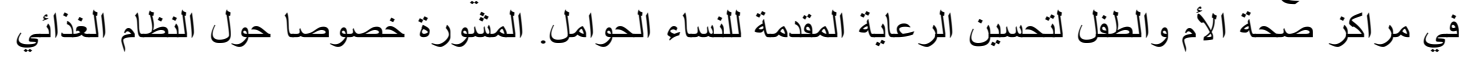

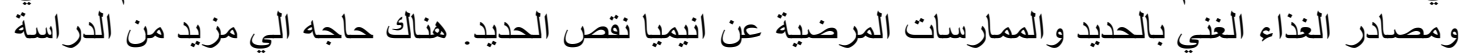

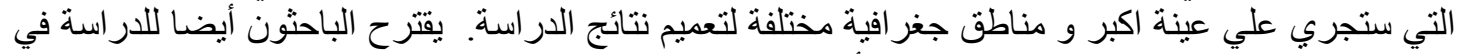
المستقبل لتشمل النظام الغذائي المتو ازن بين الأمهات قبل الو لادة. 